PREPARED IN COOPERATION WITH THE

STATE OF CONNECTICUT

GEOLOGICAL AND NATURAL HISTORY SURVEY

\title{
AEROMAGNETIC MAP OF PART OF THE GUILFORD QUADRANGLE, NEW HAVEN COUNTY, CONNECTICUT
}

\author{
GEOPHYSICAL INVESTIGATIONS \\ MAP GP-875
}

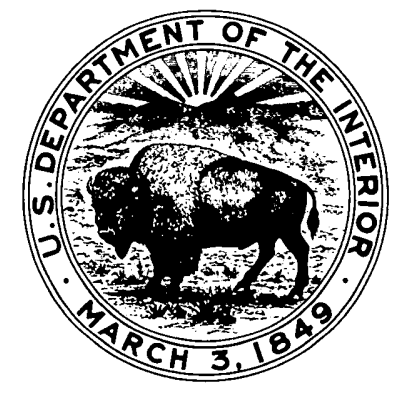

